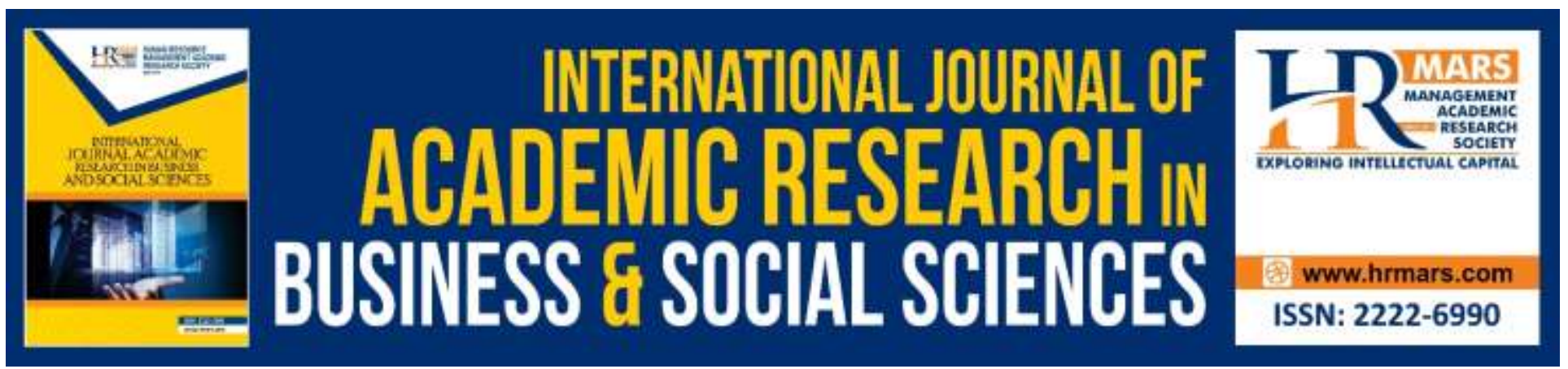

\title{
Analysis of Student Abilities in Solving Mathematical Problems of National Examination at High School Level
}

Sumardi, M. Ikhsan, M. Duskri

To Link this Article: http://dx.doi.org/10.6007/IJARBSS/v10-i6/7327

DOI:10.6007/IJARBSS/v10-i6/7327

Received: 02 March 2020, Revised: 22 April 2020, Accepted: 29 May 2020

Published Online: 02 June 2020

In-Text Citation: (Sumardi et al., 2020)

To Cite this Article: Sumardi, Ikhsan, M., \& Duskri, M. (2020). Analysis of Student Abilities in Solving Mathematical Problems of National Examination at High School Level. International Journal of Academic Research in Business and Social Sciences, 10(6), 482-491.

Copyright: (c) 2020 The Author(s)

Published by Human Resource Management Academic Research Society (www.hrmars.com)

This article is published under the Creative Commons Attribution (CC BY 4.0) license. Anyone may reproduce, distribute, translate and create derivative works of this article (for both commercial and non-commercial purposes), subject to full attribution to the original publication and authors. The full terms of this license may be seen at: http://creativecommons.org/licences/by/4.0/legalcode

Vol. 10, No. 6, 2020, Pg. 482 - 491

http://hrmars.com/index.php/pages/detail/IJARBSS

JOURNAL HOMEPAGE

Full Terms \& Conditions of access and use can be found at http://hrmars.com/index.php/pages/detail/publication-ethics 


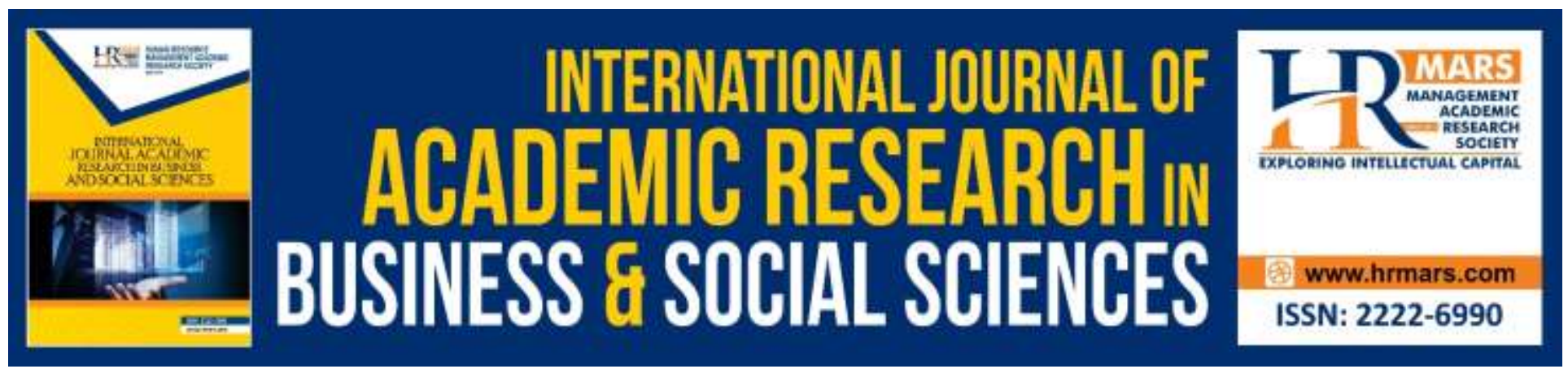

\title{
Analysis of Student Abilities in Solving Mathematical Problems of National Examination at High School Level
}

\author{
Sumardi ${ }^{1}$, M. Ikhsan², M. Duskri ${ }^{3}$ \\ ${ }^{1,2}$ Mathematics Education Program, Universitas Syiah Kuala, Banda Aceh, Indonesia, ${ }^{3}$ Mathematics \\ Education Program, Universitas Islam Negeri Ar-Raniry, Banda Aceh, Indonesia \\ Email: ikhsan@unsyiah.ac.id
}

\begin{abstract}
The implementation of the National Examination (UN) is a government policy that aims to measure the competency achievement of graduates nationally on certain subjects, including mathematics. Mathematics with various roles makes it a very important science, among others, as a thinking tool to train students to solve or solve everyday problems. The purpose of this study is to analyze the ability, the type of error made, and the factors that cause students to make mistakes in completing math test questions. This type of research is qualitative research. The subjects in this study were Year 12 students of IPA 1 and IPA 3 of 11 students. The instruments in this study were mathematics questions of high school examinations year 2015/2016 that contained the indicator of problem solving and interview guidelines. Based on the analysis of test results and interviews, students' reasoning abilities in solving the National Examination are still low. Errors made by students include: 1) still mistakenly applying mathematical formulas and propositions in solving problems; 2) wrong in doing mathematical manipulation; 3) cannot draw logical conclusions; 4) cannot interpret questions into the form of mathematical models; and 5) wrong in using patterns and relationships to analyze mathematical situations. The factors that cause students to make mistakes include 1) students lack training independently by solving more varied questions; 2 ) material that has been studied is not well remembered, so mastery of the basic concepts of prerequisite material is still weak; 3 ) students tend to abbreviate answers and are not used to writing conclusions from an answer to a problem; 4) the existence of misconceptions in students; 5) students cheat on the work of other students; and 6) many students view mathematics as the most difficult field of study. Teachers are expected in learning activities to provide problems that demand students 'thinking reasoning in solving a problem so as to improve students' reasoning ability in solving math problems.
\end{abstract}

Keywords: Student Ability, National Examination, Mathematics Problem. 
INTERNATIONAL JOURNAL OF ACADEMIC RESEARCH IN BUSINESS AND SOCIAL SCIENCES Vol. 10, No. 6, June, 2020, E-ISSN: 2222-6990 @ 2020 HRMARS

\section{Introduction}

The implementation of the National Examination (UN) is a government policy that aims to measure the achievement of graduate competencies nationally on certain subjects, among the subjects covered by the National Examination is mathematics. Mathematics with various roles makes it a very important science, one of which is a thinking tool to train students to solve or solve everyday problems.

The National Examination is a government policy to determine education quality standards. According to Minister of National Education Regulation No. 20 of 2007 concerning Educational Assessment Standards, the National Examination which is hereinafter referred to as UN is an activity of measuring the achievement of competency of students in several subjects of science and technology in order to assess the achievement of national education standards. The following is presented in the table of results of the National Examination (UN) in high school mathematics subjects in the district of West Aceh in the last four years.

Table 1. High School Mathematics National Examination (UN) Results in West Aceh District

\begin{tabular}{|l|l|l|l|}
\hline School Year & The Highest Score & The Lowest Score & Average Score \\
\hline $2011-2012$ & 9,50 & 3,30 & 7,64 \\
\hline $2012-2013$ & 9,30 & 4,50 & 6,21 \\
\hline $2013-2014$ & 9,00 & 3,60 & 5,51 \\
\hline $2014-2015$ & 90,0 & 5,0 & 47,25 \\
\hline
\end{tabular}

Data source: Aceh Provincial Education Office.

Based on these scores, the mathematical score of the results of the National Examination is still relatively low. One reason for the failure of students in mathematics is because students are unable to use their reasoning well in solving mathematical problems. Ability is the basis for having attitude and habits of critical thinking. The ability to think mathematically has received much attention from researchers and education. The idea of mathematical activity that focuses on mathematical thinking skills views mathematics as an active, dynamic, generative, and explorative process. Henningsen and Stein (Sumarmo, 2000: 6) named the mathematical process in terms of reasoning and high-level mathematical thinking (high-level mathematical thinking and reasoning).

The low mathematics learning outcomes are influenced by many factors. The lack of abilities and errors of students in solving mathematical problems is included in the factors, thus these errors need to be identified and what factors influence them are sought. Thus, information about errors in solving mathematical questions can be used to improve the quality of teaching and learning activities and ultimately can improve students' mathematics learning achievements.

The formulation of the problem in this study is: what is the ability of students to solve the high school math exam? what kinds of mistakes do students make in completing high school National Examination math questions? and what factors cause students to make mistakes in completing high school National Examination math questions?

\section{Methods}

This study uses a qualitative approach with a type of descriptive research. This research data is in the form of facts that are presented in accordance with the reality that occurred in the study. Qualitative methods refer to research procedures that produce qualitative data, such as people's expressions or notes or people's behavior. This approach refers to the conditions of the individual as 
INTERNATIONAL JOURNAL OF ACADEMIC RESEARCH IN BUSINESS AND SOCIAL SCIENCES Vol. 10, No. 6, June, 2020, E-ISSN: 2222-6990 @ 2020 HRMARS

a whole (Sugiyono, 2011). The process observed is student activities when completing the National Examination math problem. In addition, the researcher acts as a key instrument because the researcher plans, designs, implements, collects data, analyzes data, draws conclusions, and compiles research reports.

SMA Negeri 2 Meulaboh received an A accreditation with students from various junior high schools in the district of West Aceh. The spread of students in each class is not evenly distributed because in this school the superior class, moderate ability, and ability are below average. The student's ability is obtained through the results of tests in determining majors. This is the consideration of researchers to choose this school to be the subject of research. The selected students came from class XII.IPA.1 as superior class and class XII.IPA.3 with moderate ability students. The research subjects were 11 students.

The instruments in this study are the main and supporting instruments. The main instrument is the researcher himself. Supporting instruments are mathematical ability test sheets, in the form of high school level UN questions that are modified multiple choice form questions into description questions so that researchers can find out the percentage level of students' ability to solve high school mathematics examinations in the high school year 2015/2016; interview guidelines that serve as a reference or guideline for researchers so that the interviews are directed. The interview guide in this study is structured and unstructured. Structured interviews were carried out to express qualitatively about the process of students' reasoning abilities and unstructured interviews were carried out to reveal errors and factors that led to student errors in solving mathematical problems.

The test collection techniques in this study were tests and interviews. To check the validity (validation) of qualitative data, triangulation is used. Triangulation is essentially a multimethod approach carried out by researchers when collecting and analyzing data. The triangulation used in this study is the triangulation of data sources, namely exploring the truth of certain information through various methods and sources of data acquisition.

The data analysis technique used in this study is qualitative data analysis by Miles and Huberman (1992) namely data reduction, data presentation, In the data reduction stage, data that is not in accordance with the research objectives is not used. Only data that fits the research objectives chosen, so that the data becomes clearer and simpler. Data obtained from interviews will be presented in writing. The process of data reduction begins by examining all data obtained from various sources, namely from interviews and the results of the tests given. At the data presentation stage, the researcher presents data which is the result of data reduction. Data is categorized in the form of narrative text. The data that has been presented can facilitate researchers in mastering and understanding the data as a source in drawing the right conclusions. At the stage of drawing conclusions, the researcher summarizes the data and verifies the data that has been collected about students' reasoning abilities in completing high school National Examination questions in class XII.IPA.1 and XII.IPA.3 of SMA Negeri 2 Meulaboh.

Then scoring of student answers is then carried out. Students will be given a formula:

$$
\text { Student Score }=\left(\frac{\text { Score Obtained }}{\text { Maximal Score }} \times 700\right)+100
$$

These values were analyzed descriptively qualitatively and quantitatively and grouped in the following categories: 
INTERNATIONAL JOURNAL OF ACADEMIC RESEARCH IN BUSINESS AND SOCIAL SCIENCES Vol. 10, No. 6, June, 2020, E-ISSN: 2222-6990 @ 2020 HRMARS

Table 2. Categories of Student Ability Based on TIMSS 2011

\begin{tabular}{|c|c|}
\hline Scores & Information \\
\hline $625-800$ & Advance \\
\hline $550-624$ & High \\
\hline $475-549$ & Intermediate \\
\hline $100-474$ & Low \\
\hline
\end{tabular}

Source : TIMSS 2011

\section{Result}

This research includes preliminary study activities, preparation of research instruments, validation of research instruments, triangulation, tests, analysis of test results, interviews, and analysis of interview results. At the stage of the preliminary study, the researcher conducted a curriculum analysis, analysis of high school level National Examination questions for the 2015/2016 academic year, as well as the scoring rubric. At the preparation stage of the research instrument, the researcher chose the high school National Examination questions for the 2015/2016 school year according to curriculum analysis. The questions produced at this stage are 8 questions. The researcher made a self-assessment of the results of the 2015/2016 National High School Exam questions.

At the stage of validation of the research instrument, the researcher asks for opinions and suggestions from several experts (lecturers, teachers, and colleagues) who are experienced in mathematics education as a problem validator that has been prepared in the previous stage. Suggestions and opinions from the validator are expected to contribute to the improvement of the instrument by researchers, especially in the steps to solving the problem. In the triangulation phase, researchers use written documents, notes or personal writing of students, regarding material that is in accordance with the research instrument, which has been studied before, as well as analysis of test results and interviews.

In the test phase, students who were the subjects of the study completed 8 items of high school level UN questions that were modified to become a matter of description. In the next stage researchers interviewed several students who made mistakes in solving the questions given. The interview aims to find out the factors that caused the errors in completing the high school exam questions in the 2015/2016 school year. 
INTERNATIONAL JOURNAL OF ACADEMIC RESEARCH IN BUSINESS AND SOCIAL SCIENCES Vol. 10, No. 6, June, 2020, E-ISSN: 2222-6990 @ 2020 HRMARS

\section{ABILITY OF STUDENTS TO COMPLETE THE NATIONAL EXAMINITION}

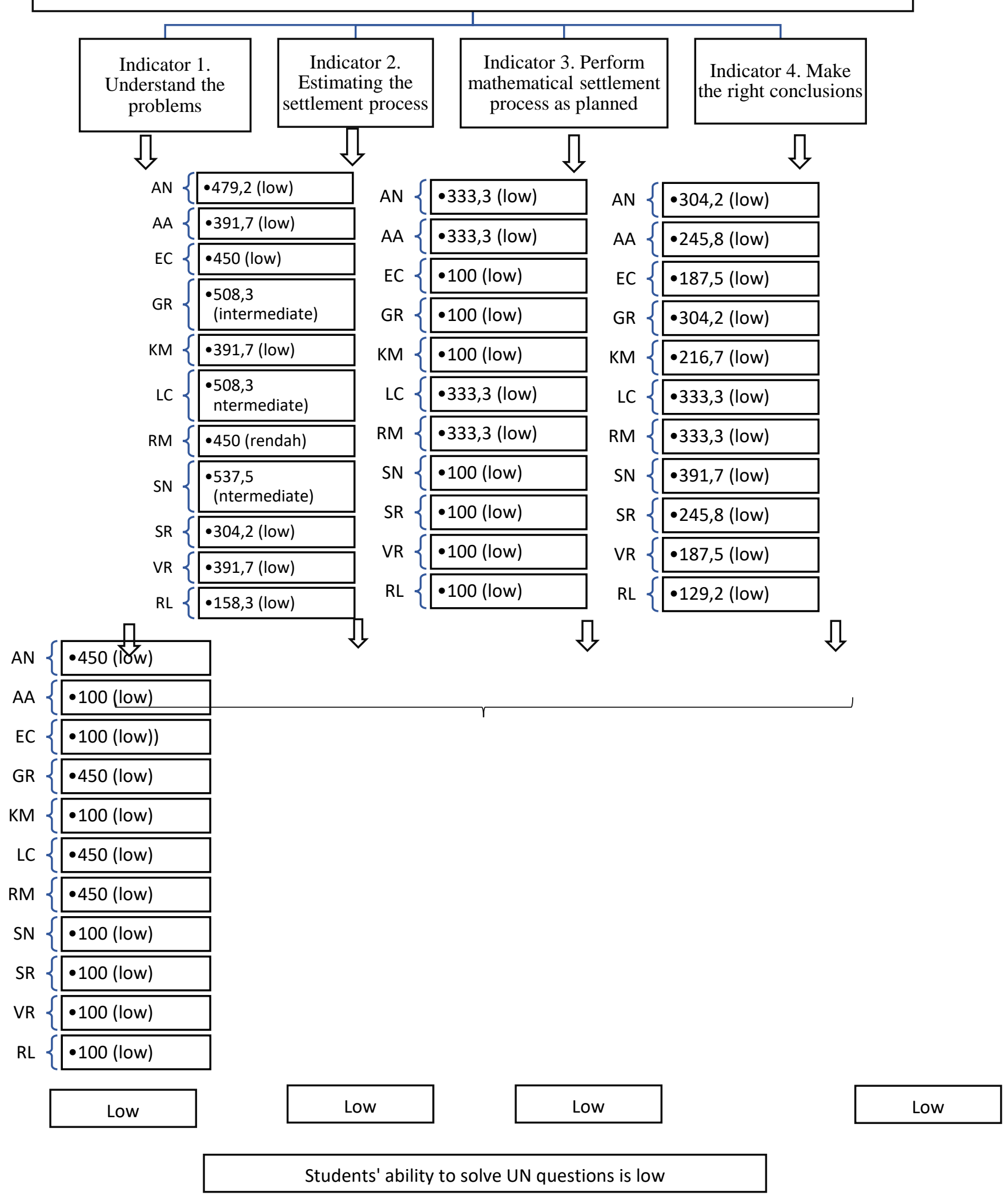

Figure 1. Results of Student Test Analysis 
Based on the picture above, on indicator 1 , there were 4 out of 11 students getting a score of 479.2 to 537.5 which was included in the intermediate category of the maximum score, which is 800 . Seven other students scored 158.3 to with 450 included in the low ability category. With the acquisition of such scores, students' reasoning ability in estimating the mathematical problem solving process based on TIMSS 2011 benchmark is included in the low category.

On indicator 2, eleven students obtained a score of 100 to 333.3 which was included in the low ability category. With the acquisition of such scores, students' reasoning abilities to provide explanations using models, facts, traits and relationships in solving mathematical problems based on TIMSS 2011 benchmarks include the low category.

On indicator 3, eleven students obtained a score of 129.2 to 391.7 which was included in the low ability category. With the acquisition of such scores, students' reasoning abilities in performing mathematical manipulations to solve problems based on TIMSS 2011 benchmarks include the low category.

On indicator 4, eleven students obtained a score of 100 to 450 which was included in the low ability category. With the acquisition of such scores, students' reasoning abilities in drawing logical conclusions to solve problems based on TIMSS 2011 benchmarks include the low category.

In addition, the factors that cause students to make mistakes in solving math problems can be identified if the students have made mistakes. Broadly speaking, the factors that influence errors can be divided into two groups, namely internal and external factors. Internal factors are factors that originate from within human learning. Whereas external sources are called external factors.

The factors that cause students to make mistakes in solving mathematical problems are the students who do not practice independently by solving more varied questions. Based on humanistic learning theory (Rogers, 1983), learning will be most significant and pervasive when carried out on its own initiative; when learning involves the student's feelings and thoughts.

The second factor is the material that has been studied is not well remembered, so mastery of the basic concepts of prerequisite material is still weak. Material from the teacher; also called information received by students stored in short-term memory. According to Dwijandono (2004: 153), short-term memory is a temporary storage system that can store information in a limited way. If you stop remembering that information, it will disappear from short-term memory.

The third factor is that students tend to abbreviate answers and are not used to writing conclusions from an answer to a problem. Students are also in a hurry and less careful in carrying out calculations so that students do not write down in detail the completion of the problem given.

The fourth factor is the occurrence of misconceptions in students. Whereas, in Piaget's theory of cognitive development, adolescence is a transition stage from the use of concrete operating reasoning to the application of formal operations. This stage is experienced by children aged 11 years and continues into adulthood. The characteristics of this stage are the ability to think abstractly, reason logically, and draw conclusions from available information. According to Piaget, adolescents have the ability to think systematically, that is, they can think of all the possibilities to solve a problem. Teenagers can think flexibly because they can see all the elements and possibilities that exist. And teenagers can think effectively because they can see which thoughts are suitable for the problems at hand.

The fifth factor is students cheating the work of other students, so the answers obtained at the time of the test are different from the interviews. Cheating behavior is caused by lazy attitudes 
embedded in students so that they are left behind in mastering subjects. In fact, this cheating behavior will lead to behavior or character not confident, undisciplined, and irresponsible.

The sixth factor is that many students view mathematics as the most difficult field of study. Even so students must learn it because it is a means to solve the problems of everyday life. Like language, reading and writing, the difficulty of learning mathematics must be overcome as early as possible. Otherwise students will face many problems because almost all fields of study require mathematics (Abdurrahman, 1999: 251).

The results obtained above are an elaboration of the test value data obtained and combined with the results of interviews with the research subjects. It is possible that there are still other factors that cause students to make mistakes in solving math problems, which are not revealed either from the results of the tests or interviews.

\section{Discussion}

The National Examination aims to assess the achievement of graduates' competencies nationally on the subjects determined from the subjects of science and technology. Mathematics includes the subject being tested. In this study, the ability of students to complete the National Examination questions at the high school level for the 2015/2016 school year is included in the low category. The question that became the instrument of this research was 8 items.

The researcher categorized the ability of students to complete the UN question based on TIMSS. The capability indicators used are Polya (1956). On indicator 1) understand the problem; there are 4 out of 11 students getting a score of 479.2 to 537.5 which is included in the intermediate ability category. Seven other students scored 158.3 to 450 which were included in the low ability category. The maximum score is 800 . Many students still mistakenly apply mathematical formulas and propositions in solving problems. Therefore, students' reasoning ability in estimating the mathematical problem solving process based on TIMSS 2011 benchmark is low.

In indicator 2) estimating the settlement process; there were 11 students who scored 100 to 333.3 so that they were included in the low ability category. Therefore, students' reasoning ability to provide explanations using models, facts, traits and relationships in solving mathematical problems based on TIMSS 2011 benchmark is low.

In indicator 3), completing the settlement as planned, there are 11 students obtaining a score of 129.2 to 391.7 which is included in the low ability category. Students do not remember well the material that has been studied before, so mastery of the basic concepts of prerequisite material is still weak. Therefore, with the acquisition of such scores, students' ability to use patterns and relationships to analyze mathematical situations based on TIMSS 2011 benchmark is low. Students are often in a hurry and less careful in carrying out calculations so that students do not write down in detail the completion of the problem given. Therefore, students' ability to do mathematical manipulation to solve problems based on TIMSS 2011 benchmark is low.

On indicator 4), eleven students obtained a score of 100 to 450 which was included in the low ability category. With the acquisition of such scores, students' reasoning ability in drawing logical conclusions to solve problems based on TIMSS 2011 benchmark is low. Students tend to abbreviate answers and are not used to writing conclusions from an answer to a problem, so that the score obtained becomes reduced. 
INTERNATIONAL JOURNAL OF ACADEMIC RESEARCH IN BUSINESS AND SOCIAL SCIENCES

Vol. 10, No. 6, June, 2020, E-ISSN: 2222-6990 @ 2020 HRMARS

\section{Conclusions}

The conclusions of this study are: students' reasoning ability in solving mathematics questions on the National Examination at the high school level in the academic year 2015/2016 is still low. This is due to an error made by students in solving math problems. Errors made by students include: still mistakenly applying mathematical formulas and propositions in solving problems, erroneous in doing mathematical manipulation, unable to draw logical conclusions, unable to interpret problems to form mathematical models, and incorrectly using patterns and relationships to analyze mathematical situations. This is in accordance with the error indicator according to Budiono (2008), namely the error in determining the theorem or formula to answer the problem, errors in entering data into variables, errors in interpreting symbols, graphs and tables into mathematical language, errors in manipulation of algebraic operations, and doing the conclusion of statements that are not in accordance with logical reasoning.

While the factors that cause students to make mistakes in solving math problems include: students do not practice independently in solving more varied problems, the material that has been studied is not well remembered so that mastery of the basic concepts of prerequisite material is still weak, tends to shorten answers and not accustomed to writing the conclusions of an answer to a problem, the existence of misconceptions in students, cheating on the work of other students and many students who view mathematics as the most difficult field of study. This is in accordance with the results of Wahbi \& Bey's research (2015) that the factors that cause students to make mistakes namely students do not understand how to operate algebraic forms properly and correctly, students do not master the concepts related to algebraic operations, students do not understand the questions well and students are not careful in working on problems and students sometimes do not understand the material taught by the teacher.

\section{Suggestions}

Based on the results of research and conclusions, there are several suggestions: for students, to multiply complete variations in mathematical questions that require mathematical abilities; for mathematics teachers, it is better to more often give problems that require reasoning to think students in solving a problem so that it does not only focus on the procedural skills that students do; for other researchers, this study only reveals the causes of errors and causes that originate from students, therefore it is advisable to continue this research by revealing the causes of student errors caused by teachers, learning contexts, textbooks and teacher teaching methods, and ways to overcome mistakes that is.

\section{Reference}

Abdurrahman, M. (1999). Pendidikan bagi anak berkesulitan belajar. Jakarta: Rineka Cipta.

Budiyono. (2008). Kesalahan mengerjakan soal cerita dalam pembelajaran matematika. Jurnal Paedogogia, 11(1), 1-8.

Dwijandono, S. E. W. (2004). Psikologi pendidikan. Jakarta: Grasindo.

Miles, M. B., \& Huberman, A. M. (1992). Analisis data kualitatif. Diterjemahkan oleh Tjetjep Rohidi. Jakarta: Universitas Indonesia Press.

Minister of National Education Regulation No. 20/2007 Concerning Education Assessment Standards. Jakarta: Directorate General of Primary and Secondary Education Management.

Polya, G. (1973). How to solve it a new aspect of mathematical method. By Princeton University Press. 
INTERNATIONAL JOURNAL OF ACADEMIC RESEARCH IN BUSINESS AND SOCIAL SCIENCES

Vol. 10, No. 6, June, 2020, E-ISSN: 2222-6990 @ 2020 HRMARS

Rogers, E. M. (1983). Diffusion of Innovations. New York: Free Press.

Sugiyono. (2013). Metode penelitian pendidikan pendekatan kuantitatif, kualitatif, dan R\&D. Bandung : Alfabeta.

Sumarmo, U. (2000). Pengembangan model pembelajaran matematika untuk meningkatkan kemampuan intelektual tingkat tinggi siswa sekolah dasar. Study report in Faculty of Mathematics and Science Education, Bandung: Lembaga Penelitian Bandung, unpublished.

TIMSS. (2011). TIMSS 2011 assessment frameworks. Chestnut Hill, MA, USA: TIMSS \& PIRLS International Study Center.

TIMSS. (2011). TIMSS 2011 international results in mathematics. Chestnut Hill, MA, USA: TIMSS \& PIRLS International Study Center.

Wahbi, A., \& Bey, A. (2015). Analisis kesalahan siswa dalam menyelesaikan soal faktorisasi suku aljabar ditinjau dari objek matematika pada siswa kelas VIII SMP Negeri 15 Kendari. Jurnal Penelitian Pendidikan Matematika, 3(1), 17-30. 